\title{
Global expression analysis of EBV-infected B cells early and late after infection reveals a dynamic interplay between growth and survival signals
}

\author{
Alexander Price, Jason Tourigny, Eleonora Forte, Micah Luftig ${ }^{*}$ \\ From 13th International Conference on Malignancies in AIDS and Other Acquired Immunodeficiencies \\ (ICMAOI) \\ Bethesda, MD, USA. 7-8 November 2011
}

Epstein-Barr virus (EBV) is a member of the $\gamma$-herpesvirus family estimated to infect $90 \%$ of the world's adult population. Despite the high prevalence of infection, EBV-associated malignancies are largely kept in check by a strong cytotoxic $\mathrm{T}$ cell immune response. However, EBV causes lymphoproliferative disease in immunedeficient individuals following transplant and CNS and other lymphomas in HIV-infected individuals. EBV also plays a role in the pathogenesis of endemic African Burkitt's lymphoma, Hodgkin's disease, and nasopharyngeal carcinoma. In vitro, EBV infection of primary human B cells results in proliferation and outgrowth of indefinitely proliferating lymphoblastoid cell lines, or LCLs, which represent a viable model for the pathogenesis of EBV-associated malignancies.

Ongoing studies in our group have shown that the earliest EBV-infected proliferating B cells differ greatly from LCLs phenotypically. Using CFSE staining and flow cytometry-based sorting, we have isolated these early proliferating $B$ cells and analyzed genome-wide exon level mRNA expression relative to uninfected resting B cells and LCLs. Gene ontology analysis of these expression data identified enrichment of genes associated with proliferation and the DNA damage response in early proliferation. Furthermore, c-Myc mRNA and activity, as inferred from its genomewide expression signature, were also highly induced early.

Most interestingly, however, analysis of changes from early proliferating to final LCL outgrowth revealed striking attenuation of proliferative gene sets and c-Myc, along with delayed induction kinetics of $\mathrm{NF} \kappa \mathrm{B}$ activation. Specifically, genes with $\mathrm{NF} \kappa \mathrm{B}$ motifs in their promoters were

* Correspondence: micah.luftig@duke.edu

Department of Molecular Genetics and Microbiology, Duke University, Durham, NC, USA

(C) 2012 Price et al; licensee BioMed Central Ltd. This is an Open Access article distributed under the terms of the Creative Commons Attribution License (http://creativecommons.org/licenses/by/2.0), which permits unrestricted use, distribution, and reproduction in any medium, provided the original work is properly cited. highly expressed from early proliferating B cells to LCL and many canonical $\mathrm{NF} \kappa \mathrm{B}$ targets and pathway components were induced at late times after infection. These results suggest a novel, dynamic EBV-driven growth pattern and expression program that relies on mutually exclusive signals from c-Myc and NF $\kappa \mathrm{B}$. Furthermore, our data suggest that the earliest stages of EBV-driven B cell immortalization may provide unique insight into the pathogenesis of EBV-associated malignancies.

Published: 19 April 2012

doi:10.1186/1750-9378-7-S1-P34

Cite this article as: Price et al:: Global expression analysis of EBVinfected $B$ cells early and late after infection reveals a dynamic interplay between growth and survival signals. Infectious Agents and Cancer 2012 7(Suppl 1):P34.

Submit your next manuscript to BioMed Central and take full advantage of:

- Convenient online submission

- Thorough peer review

- No space constraints or color figure charges

- Immediate publication on acceptance

- Inclusion in PubMed, CAS, Scopus and Google Scholar

- Research which is freely available for redistribution Submit your manuscript at
www.biomedcentral.com/submit C BioMed Central \\ () Biomed Central}

